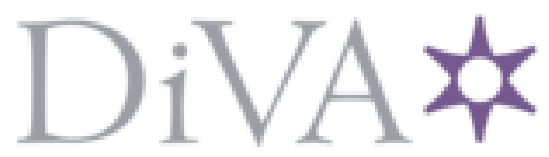

http://www.diva-portal.org

This is the published version of a paper published in Rhetorik: ein internationales Jahrbuch.

Citation for the original published paper (version of record):

Rimm, S. (2014)

Eloquence and Education: School Rhetoric in Eighteenth-Century Sweden.

Rhetorik: ein internationales Jahrbuch, 33(1): 17-26

http://dx.doi.org/10.1515/rhet.2014.004

Access to the published version may require subscription.

N.B. When citing this work, cite the original published paper.

Permanent link to this version:

http://urn.kb.se/resolve?urn=urn:nbn:se:oru:diva-40139 
Rhetorik. Ein internationales Jahrbuch

Band 33

Rhetorik im

18. Jahrhundert 
Brought to you by | De Gruyter / TCS Authenticated 


\section{Rhetorik \\ Ein internationales Jahrbuch}

Herausgegeben von

Wolfgang Neuber

Peter L. Oesterreich

Gert Ueding

Francesca Vidal

Begründet von Manfred Beetz, Joachim Dyck und Walter Jens

Band 33

Rhetorik im 18. Jahrhundert

Herausgegeben von

Dietmar Till

De Gruyter 
Herausgeber Bd. 33: Prof. Dr. Dietmar Till, Seminar für Allgemeine Rhetorik, Eberhard Karls Universität Tübingen, Wilhelmstr. 50, 72074 Tübingen.

Reihen-

herausgeber

Redaktion

Manuskripte

Rezensionen

Editeur de compte-rendus pour la France
Prof. Dr. Wolfgang Neuber Institut für Deutsche und Niederländische Philologie, Freie Universität Berlin Habelschwerdter Allee 45, 14195 Berlin

Prof. Dr. Peter L. Oesterreich augustana-Hochschule, Waldstraße 11, 91564 Neuendettelsau

Prof. Dr. Gert Ueding

Seminar für Allgemeine Rhetorik, Universität Tübingen Wilhelmstraße 50, 72074 Tübingen

PD Dr. Francesca Vidal Institut für Philosophie, Universität Koblenz-Landau Bürgerstr. 23, 1. Stock, 76829 Landau

Dr. Markus Mülke augustana-Hochschule, Waldstraße 15, 91564 Neuendettelsau email: markus.muelke@augustana.de

in deutscher, englischer oder französischer Sprache werden an die Adresse in Neuendettelsau erbeten.

Besprechungsexemplare werden an die Adresse der Redaktion erbeten. Eine Verpflichtung zur Besprechung eingesandter Schriften, soweit sie nicht angefordert worden sind, besteht nicht. Nach Erscheinen erhalten die Verlage zwei Belege der Rezensionen.

\section{Prof. Dr. Jean-Paul Sermain}

U.F.R. de Litterature et Linguistique Françaises et Latines,

Centre Censier, 13, rue Santeuil, F-75231 Paris Cedex o5

ISSN 0720-5775

e-ISSN 1865-9160

Bibliografische Information der Deutschen Nationalbibliothek

Die Deutsche Nationalbibliothek verzeichnet diese Publikation in der Deutschen Nationalbibliografie; detaillierte bibliografische Daten sind im Internet über http://dnb.d-nb.de abrufbar.

(C) 2014 Walter de Gruyter GmbH, Berlin/München/Boston

Satz: epline, Kirchheim unter Teck

Druck und Bindung: CPI books GmbH, Leck

@ Gedruckt auf säurefreiem Papier

Printed in Germany

www.degruyter.com 


\title{
Stefan Rimm
}

\section{Eloquence and Education.}

\author{
School Rhetoric in Eighteenth-Century Sweden
}

\begin{abstract}
The following contribution will examine the form and content of school rhetoric in the Latin schools of early modern Sweden. After an introduction to the schools, an outline of their curricular heritage will be given, situating school rhetoric in the classical trivium. Three components of rhetorical education are identified: the theoretical teaching, the reading of exemplary texts, and the exercises, all three components displaying a striking traditionalism and stability during the eighteenth century. Furthermore, it will be shown that rhetorical education also served as a means of instilling virtue in pupils and that rhetoric was an essential component in the reproduction of a representative learned culture and in the formation of virtuous character and erudite identity.
\end{abstract}

\section{Introduction}

As the early modern era came to a close, a classical legacy that had shaped education for more than two thousand years was about to be increasingly distrusted, and eventually dismantled as a basis for schooling. This was perhaps particularly true for rhetoric, once one of the foremost of school subjects. In Sweden the eighteenth century was a period, perhaps the last one, in which the teaching of rhetoric was still a cornerstone of a classical curriculum with its roots in Antiquity. ${ }^{1}$

In this text, I will situate rhetoric in a broader curricular context than usually is the case. I will discuss textbooks, classical authors, exercises and the remarkable stability of school rhetoric during the eighteenth century. And finally, I will consider schools as spaces for display of erudition, where eloquence and rhetorical training are seen as catalysts for the raising of schoolboys into virtuous men.

${ }^{1}$ This text draws mainly upon results from my dissertation on rhetorical education in eightheenth-century Sweden. Cf. Stefan Rimm, Vältalighet och mannafostran. Retorikutbildningen i svenska skolor och gymnasier 1724-1807 [Virtuous eloquence. Rhetoric education in Swedish Schools and Gymnasiums 1724-1807], Diss. Örebro, Uppsala 2011 (online cf. the link: http://urn.kb.se/resolve?urn=urn:nbn:se:or u:diva-17326). An English summary is given on pp. 310-319. Cf. also Stefan Rimm, Rhetoric, Texts and Tradition in Swedish 18th Century Schools, in: Otto Fischer/Ann Öhrberg (eds.), Metamorphoses of Rhetoric. Classical Rhetoric in the Eighteenth Century, Uppsala 2011, 153-172. 


\section{The Latin schools of early modern Sweden}

As the Latin schools - the trivial schools, the cathedral schools, and the gymnasiums - in early modern Sweden were state schools, yet since Protestant Reformation administered by the church, they formed the basis for an ecclesiastical-educational complex. Educating the sons of wealthier farmers, priests, merchants, soldiers and persons of rank not belonging to the nobility, the Latin Schools of eighteenth-century Sweden prepared most pupils for university studies and, eventually, for an ecclesiastical, academic or administrative career. ${ }^{2}$ Though the general framework was laid out at a national level by the School Act, at regional and local levels the clergy exerted a ubiquitous influence, with the bishops functioning as inspectors (efori) and a considerable amount teaching staff being made up by aspiring clergymen. ${ }^{3}$

The trivial schools, junior secondary schools similar to grammar schools, were - as their name suggests - centered around the trivium of the septem artes liberales. Under the Swedish School Act of 1724 the three liberal arts of rhetoric, grammar, and dialectics were the foundations of a curriculum focusing on a classical, mainly Latin, legacy language as well as the prevailing Protestant teachings. ${ }^{4}$ The trivial schools were divided into four forms, with each form divided in two circuli: inferiores and superiores. ${ }^{5}$ The pupils spent two or more years in each form, advancing from one form to the next depending on their educational progression. From the fourth form, rhetoric was an explicit part of the official curriculum, although various elements preparing for rhetoric instruction were already present in lower forms. After completing trivial school, the pupils normally went on to the gymnasiums, which were situated in cathedral towns. The gymnasiums were organised in a way similar to that of the trivial schools; having qualification for university as its ultimate goal, the advancement from one form to the next was determined by educational progression. ${ }^{6}$

As the schoolboys entered the trivial schools at about the age of eight, being expected to already be literate in the popular language, they were immediatly introduced to Latin instruction and to a noticeably text-centered education that relied heavily on a classical canon of mainly Latin texts (although Greek and Hebrew texts were also read, with the Bible as the prime example). ${ }^{7}$ Latin was not only the primary language in instruction, but was also ex-

${ }^{2}$ Cf. Wilhelm Sjöstrand, Pedagogikens historia. 3:I. Sverige och de nordiska grannländerna under frihetstiden och gustavianska tiden, Lund 1961, 145 f.; Bengt Sandin, Hemmet, gatan, fabriken eller skolan. Folkundervisning och barnuppfostran i svenska städer 1600-1850, Diss. Lund 1986, 165, and Rimm, Vältalighet och mannafostran, 82 .

3 Cf. Stefan Rimm, Textbook Supply and Shortage in Eighteenth-Century Sweden, in: Carla Aubry/Johannes Westberg (eds.), History of Schooling. Politics and Local Practice, Frankfurt a. M./Berlin/Bruxelles / New York/Oxford Wien 2012, 194, and Rimm, Vältalighet och mannafostran, 82.

${ }^{4}$ Cf. Rimm, Vältalighet och mannafostran, 83 f.; see also Hans Kongl, Maij:ts Förnyade Schole-Ordning, af Åhr 1724 [The Swedish School Act of 1724], in: Sveriges allmänna läroverksstadgar 1561-1905. Under fleras medverkan utgivna av B. Rud. Hall. IV-VI, 1693, 1724 och 1807 års skolordningar, Lund 1922, $17-65$.

5 Cf. Sjöstrand, Pedagogikens historia. 3:1, 155.

6 The socalled cathedral schools had a somewhat special status; they could encompass the education equivalent to both trivial school and gymnasium, thereby qualifying the schoolboys for direct advancement to university. Cf. for example Sjöstrand, Pedagogikens historia. 3:1, 135 f.

7 Cf. Sjöstrand, Pedagogikens historia. 3:1, 154, and Rimm, Vältalighet och mannafostran, 8of. 
pected to be spoken by the pupils throughout the school day; towards the end of the century, however, the vernacular had clearly begun to challenge the Latin supremacy. ${ }^{8}$

\section{School rhetoric's curricular heritage}

Rhetoric education in eighteenth-century schools can be seen as structured into three components: firstly: the theoretical teaching of rhetoric (praecepta), secondly, the reading of exemplary texts (lectionis exempla), and thirdly the exercises (exercitationes), both written and oral. 9

This three-part rhetoric program embodied a curricular heritage from Quintilian and the Roman rhetoric education, via late antique, medieval and Renaissance humanist education to Protestant-humanist reformers as Philipp Melanchthon. ${ }^{10}$ This way, the scope of the rhetoric education was far wider than what was actually labelled >rhetoric in school schedules. ${ }^{11}$ In this program, rhetoric's close ties to the other parts of the trivium and a classical curriculum was evident: both with regards to the general reading and writing exercises and to literature, history, mythology and theology - and of course to the overall Latin study. ${ }^{12}$

During most of the eighteenth century the schools and gymnasiums of Sweden were regulated by the School Act of 1724 - originally intended as a provisional statute - which was as a matter of fact effective for 83 years, until 1807 . However, school rhetoric changed very little during this long period of time, and the changes that took place did so only slowly. ${ }^{13}$ In this aspect, school rhetoric certainly differs from rhetoric in a broad sense. As shown by the cultural and aesthetical debates of the eighteenth century the status of rhetoric was in some instances dramatically changed. ${ }^{14}$

The explanations for the rigidity are diverse. There were a number of circumstances that affected the education in rhetoric: from governance factors and material conditions to the traditions and practices of the school room. ${ }^{15}$ As will be shown below, these circumstances had perpetuating effects on all three parts of the rhetorical educational programme.

${ }^{8}$ Cf. Rimm, Vältalighet och mannafostran, $249 \mathrm{f}$.

${ }^{9}$ Cf. Rimm, Vältalighet och mannafostran, 92 f. 194-197.

${ }^{10} \mathrm{Cf}$. Rimm, Vältalighet och mannafostran, $92 \mathrm{f}$.

${ }^{11}$ Cf. Rimm, Vältalighet och mannafostran, 194.

${ }_{12}^{12}$ Cf. Rimm, Vältalighet och mannafostran, 194-197.

${ }^{13}$ Cf. Rimm, Vältalighet och mannafostran, 297-299, and Rimm, Textbook Supply and Shortage in Eighteenth-Century Sweden, 194.

${ }^{14}$ Cf. Wilhelm Sjöstrand, Pedagogikens historia. 3:1, 119-121, and for example Otto Fischer, An End to Rhetoric? The Subject of Rhetoric in the Public Debate of the Late Eighteenth Century in Sweden, in: Otto Fischer/Ann Öhrberg (eds.), Metamorphoses of Rhetoric. Classical Rhetoric in the Eighteenth Century, Uppsala 2011.

${ }^{15}$ Cf. Rimm, Vältalighet och mannafostran, passim, and Rimm, Textbook Supply and Shortage in Eighteenth-Century Sweden, passim. 


\subsection{The praecepta}

The first, and perhaps the most obvious, part of the rhetorical pedagogical programme consisted of the praecepta, the teaching of rhetorical theory. ${ }^{16}$ The instruction was based primarily on the textbook Elementa rhetorica by Dutch scholar Gerardus Johannis Vossius (1577-1649). Vossius' volume was undisputedly the most influential textbook in the history of Swedish school rhetoric. It was prescribed by the School Acts of 1693 and 1724, it was published in 10 editions in Sweden during the eighteenth century, and it is evident from school records that it was indeed used in Swedish schools throughout the entire period. ${ }^{17}$

Neo-Aristotelian and Ciceronian, Vossius' Elementa rhetorica covered the rhetorices partes from inventio to actio - although to a varying extent - and used excerpts from the classical, mainly Roman, authors to demonstrate the rhetorical theory. ${ }^{18}$ Different editions of the Elementa rhetorica came to differ significantly over time.

Firstly: there was a question of language. Most of the Vossius editions printed in Sweden were in Latin. ${ }^{19}$ Other editions were published in the vernacular, Swedish, aiming at another audience. ${ }^{20}$ This alternative audience should also have included pupils in private instruction and those who for one reason or another were excluded from the Latin school, e. g. women. ${ }^{21}$ Secondly, several editions, already during the seventeenth century, saw revisions shifting the balance of the content belonging to the different partes of rhetoric. ${ }^{22}$ This raises ques- $^{-}$ tions of what historians of rhetoric have described as a general shift from the intellectual production of inventio to the linguistic ornamentation of elocutio, taking place during the period. $^{23}$

In order to examine the theoretical teachings of school rhetoric - based on a Greek and Roman legacy and interpreted and formulated in an originally seventeenth-century humanist textbook - one must examine the contents of the different Vossius editions as well as how these textbooks were actually used in rhetoric instruction.

As established by the Swedish School Act of 1724 every school and gymnasium should be supplied with the books required for instruction, and these books were expected to be made

${ }^{16}$ Cf. Rimm, Vältalighet och mannafostran, 95-137.

17 Cf. Hans Kongl, May:tz Nådige Förordning, angående Gymnasier och Scholar i Rijket. Gifwen Stockholm den 31 Januarii, Åhr 1693 [The Swedish School Act of 1693], in: Sveriges allmänna Läroverksstadgar 1561-1905. Under fleras medverkan utgivna av B. Rud. Hall. IV-VI, 1693, 1724 och 1807 års skolordningar, Lund 1922, 11. [The Swedish School Act of 1724], 43, and Rimm, Vältalighet och mannafostran, 110-119.

18 Cf. Rimm, Vältalighet och mannafostran, 77f., 126-137, and Thomas M. Conley, Rhetoric in the European Tradition, Chicago 1994, 157. 160.

19 Cf. Rimm, Vältalighet och mannafostran, 118. - For a eighteenth-century Latin edition of Elementa rhetorica printed in Sweden, cf. for example Gerardus Johannis Vossius, Gerardi Jo. Vosii Elementa rhetorica, cum auctario Mitternachtii, ejusdemq'; usu figurarum rhetoricarum, Stockholm 1707.

${ }^{20}$ Cf. Rimm, Vältalighet och mannafostran, 118, and Rimm, Textbook Supply and Shortage in Eighteenth-Century Sweden, 198. For example Gerardus Johannis Vossius, Gerhard. Joh. Wossii Elementa rhetorica, i Swenska Språket vttolkade, och Then Studerande Ungdomen til tienst i liuset framgifne. Stockholm, tryckt hos Peter Jör. Nyström, 1732, Stockholm, 1732.

${ }^{21}$ Cf. Rimm, Vältalighet och mannafostran, 117-119, and Rimm, Textbook Supply and Shortage in Eighteenth-Century Sweden, 198.

${ }^{22}$ Cf. Stina Hansson's commentary in Gerardus Johannis Vossius, Elementa rhetorica eller retorikens grunder, Göteborg 2006, 39-41, available online: http://hdl.handle.net/2077/19624.

23 Cf. Hansson in Vossius, Elementa rhetorica eller retorikens grunder. 
available to the pupils for an affordable price. ${ }^{24}$ The consistories could contract their own printers, or they could procure textbooks in a number of other ways, including buying books at the bookstores, from book commissioners or at book auctions. ${ }^{25}$ Nevertheless, textbook supply and demand rarely met. In eighteenth-century Sweden, a lack of textbooks was a common problem. ${ }^{26}$

This shortage led to the frequent use of older books, which for example could be bought at auctions or inherited from older relatives or former pupils. ${ }^{27}$ In other cases, pupils could be missing textbooks altogether. With the schools lacking in resources and the schoolboys often being poor, those who couldn't afford their own books thus had to deal with this problem as best they could: by borrowing books to read or to copy. ${ }^{28}$

On a school level, the teachers and the rectores had no authority to decide on which textbooks should be used in instruction; all changes in the literature had to be approved by the bishop and the consistory. ${ }^{29}$ Thus, changes to the syllabus were highly unusual, and the Elementa rhetorica could easily uphold the dominant position it had been given by the School Act. There were only a few digressions from the prescribed reading. ${ }^{30}$

Taken together, the above-mentioned regulatory factors led to a striking traditionalism in the teaching of rhetorical theory. ${ }^{31}$ By comparing the School Act and the various editions of Elementa rhetorica as well as other educational materials, one can identify a set of tropes and figures that make up the elocutio-centered part of Swedish school rhetoric. ${ }^{32}$ In this aspect, the theoretical rhetoric instruction might seem to be essentially concerned with the ornate language, as previous research has indicated. This elocutio-centered theoretical core was however not the only component in school rhetoric.

The education in rhetoric should, as stated above, be regarded as part of a larger program that also included the reading of exemplary texts as well as the written and oral exercises, and it is in these parts that the conceptual, intellectual educational content of rhetoric's inventio and dispositio can be found.

\subsection{The lectionis exempla}

The second part of the rhetorical pedagogical programme in the eighteenth-century schools and gymnasiums consisted of lectionis exempla, the reading of exemplary texts. ${ }^{33}$ A canon of classical, especially Latin, texts connected the branches of the trivium: grammar, dialectics

\footnotetext{
24 [The Swedish School Act of 1724], 34; cf. Rimm, Vältalighet och mannafostran, 10o, and Rimm, Textbook Supply and Shortage in Eighteenth-Century Sweden, 197.

${ }^{25}$ Cf. Rimm, Vältalighet och mannafostran, Ioof.

${ }^{26}$ Cf. for example Rimm, Vältalighet och mannafostran, 101-104.

27 Cf. Rimm, Textbook Supply and Shortage in Eighteenth-Century Sweden, $201 \mathrm{f}$.

${ }^{28}$ Cf. Rimm, Vältalighet och mannafostran, 107, and Rimm, Textbook Supply and Shortage in Eighteenth-Century Sweden, 200-202.

29 [The Swedish School Act of 1724], 36; cf. Rimm, Vältalighet och mannafostran, 97, and Rimm, Textbook Supply and Shortage in Eighteenth-Century Sweden, 196f.

30 Cf. Rimm, Vältalighet och mannafostran, 120-126.

${ }^{1}$ Cf. Rimm, Vältalighet och mannafostran, 103.

${ }^{2}$ Cf. Rimm, Rhetoric, Texts and Tradition in Swedish 18th Century Schools, 136f.

33 Cf. Rimm, Vältalighet och mannafostran, 138-161.
} 
and rhetoric. As these texts - from fables and the short texts of compendia used in the first forms of the trivial schools to the philosophical and literary works used in the gymnasiums were read throughout the school, they constituted a common resource and a common legacy. The canon was also utilised in rhetoric instruction, with pupils identifying and extracting tropes and rhetorical figures in the classical texts as part of the training in elocutio. ${ }^{34}$ The selection of these texts was, as in the case of rhetoric textbooks, tradition-bound, and did not change significantly during the period. ${ }^{35}$ In addition to the works of the ever-important Cicero, the pupils studied classical authors like Cornelius Nepos, Virgil and Ovid. ${ }^{36}$

In addition to displaying the tropes and rhetorical figures of the outstanding Roman eloquence, the works of the classical authors furthermore contained other dimensions, of historical, mythological, literary, and moral educational content. ${ }^{37}$ This clearly illustrates the versatility of the exemplary reading. The educational content of the auctores classici was furthermore reproduced by the pupils: in working with the classical texts, adding material to their own rhetorical repertoires, memorizing it or writing it down in thesauri. ${ }^{38}$

Rhetoric's dependence on the exemplary classical texts is with a further explanatory factor for the slow changes of eighteenth-century rhetoric education. The texts were a fabric interweaving rhetoric instruction and a classical legacy.

\subsection{The exercitationes}

In the third branch of the rhetorical educational programme, the exercitationes or the written and oral exercises, the pupils were made co-creators of classical-rhetorical traditions. ${ }^{39}$ Even though it can be hard to separate written from oral elements in rhetoric instruction, school rhetoric during the eighteenth century was clearly oriented towards the written word. $4^{40}$ The exercises began with the fundamentals of writing and went on to translation exercises (themata) and then to more advanced tasks. ${ }^{41}$ Considerable time was devoted to the exercitia stili, the exercises in style, perhaps the most important exercises of rhetoric as well as of Latin in general. ${ }^{42}$ Exercitia stili were generally based on imitations and variations, and the most important pedagogical principles were the concepts of imitatio and aemulatio, as had once been outlined by Quintilian. ${ }^{43}$ Here, the model - normally Cicero - should be imitated with regards both to style and content, something that indeed effected the production of rhetorical texts.

\footnotetext{
34 Cf. Rimm, Vältalighet och mannafostran, 146-151.

35 Cf. Rimm, Vältalighet och mannafostran, 151-155.

${ }^{36}$ Cf. Rimm, Vältalighet och mannafostran, 151.

37 Cf. Rimm, Vältalighet och mannafostran, 146.

$3^{8}$ Cf. Rimm, Vältalighet och mannafostran, 158-161; also Stina Hansson, Salongsretorik. Beata Rosenhane (1638-74), hennes övningsböcker och den klassiska retoriken, Göteborg 1993, 130, and Hans Helander, Neo-Latin Literature in Sweden in the Period 1620-1720. Stylistics, Vocabulary and Characteristic Ideas, Uppsala 2004, 174 .

39 Cf. Rimm, Vältalighet och mannafostran, 162-197.

$4^{\circ}$ Cf. Rimm, Vältalighet och mannafostran, 162-163. 196.

${ }^{41}$ Cf. Rimm, Vältalighet och mannafostran, 166-171.

${ }^{42}$ Cf. Rimm, Vältalighet och mannafostran, 172-18o.

43 Cf. Rimm, Vältalighet och mannafostran, 172-180. 185-193.
} 
Just like the exemplary reading, the exercises that were part of the rhetorical educational programme contained a historical or moral content. ${ }^{44}$ This way, writing exercises were a part of the pupils' moral education as well as a source for their growing rhetorical repertoire of exempla and loci (i. e. the examples and the topics or the intellectual splaces< where arguments were discovered). ${ }^{45}$

In addition to the extensive writing, the School Act of 1724 also prescribed oral rhetorical exercises. ${ }^{46}$ Among these were exercitia disputatoria, debate exercises modelled on university disputations. The theses and arguments were supposed to be logically correct and morally improving, without any oratorical extravagance - evidence of a scholastic heritage. ${ }^{47}$ In addition, there were practice speeches, exercitia oratoria, delivered in free form (prose) or bound form (verse). ${ }^{4}$ Both theses and orations were on occasion published in printed or handwritten form and given a wider circulation. ${ }^{49}$ Finally, the students also got to engage in practice sermons, exercitia concionatoria, under proper supervision of a theology teacher. ${ }^{50}$ These sermons could take place either in school, in front of one's school fellows, or in a church in front of the congregation..$^{{ }^{1}}$ In all these rhetorical exercises, it is probably safe to say that the guidance and supervision of teachers must have had a preserving effect.

\section{Setting the good example}

The aim of schooling was explicitly twofold: knowledge and virtue - thus far more than the mere transmission of information and skills. This idea was expressed clearly in the School Act of 1724: to the aims of education belonged molding pupils into good men and God-fearing citizens. ${ }^{52}$ It was therefore essential that virtue was instilled already from a young age. As a result, pupils should all times be exposed to morally uplifting texts. This moral-educational aspiration is prominent both in the texts read in schools, and in the texts that the pupils themselves produced, particularly in the rhetorical educational programme.

As discussed above, eighteenth-century rhetoric has often been seen as increasingly focused on the linguistic ornamentation of elocutio, and less interested in the intellectual processes of inventio. By examining the dominant textbook, Elementa rhetorica, however, we get a slightly more contradictory picture, showing how school rhetoric could keep more of its content-oriented aspects than has usually been emphasized. Although many of the eighteenth-century editions of Elementa rhetorica had their sections on inventio abridged, they all retained most of the morally educative content..$^{53}$ Fundamental to the

44 Cf. Rimm, Vältalighet och mannafostran, 178.

45 Cf. Rimm, Vältalighet och mannafostran, 178.

$4^{6}$ [The Swedish School Act of 1724], 55. Cf. Rimm, Vältalighet och mannafostran, 181, and Carina Burman, Vältalaren Johan Henric Kellgren, Diss. Uppsala 1988, 33.

47 Cf. Rimm, Vältalighet och mannafostran, 181-183.

$4^{8}$ Cf. Rimm, Vältalighet och mannafostran, 184 .

49 Cf. Rimm, Vältalighet och mannafostran, 184 .

${ }^{\circ} \mathrm{Cf}$. Rimm, Vältalighet och mannafostran, $184 \mathrm{f}$.

${ }^{11}$ Cf. Rimm, Vältalighet och mannafostran, 185.

${ }^{52}$ Cf. Rimm, Vältalighet och mannafostran, $202 \mathrm{f}$.

53 Cf. Rimm, Vältalighet och mannafostran, 204-211. 
delivery of this content were the rhetorical concepts of loci and exempla. As the Elementa rhetorica used excerpts from the classical authors to illustrate the linguistic ornamentation in elocutio, the texts were also filled with moral content. ${ }^{54}$ Historical events and good - or bad - examples offered moral lessons. Virtues and vices provided guidance on desirable and undesirable actions and character traits. These virtues and vices were indeed only a subsection of the loci that were used to describe, honour or revile a man. Nevertheless they offer a good illustration of what was seen as exemplary (diligence, honour, wisdom, self-control, faithfulness, and so on) or objectionable (sloth, gluttony, lust, cowardice, wastefulness, and so on). ${ }^{55}$ In the classical excerpts found in the Elementa rhetorica, the concept of virtue was based on originally antique notions of masculinity and civic ideals. The opposite of virtue i. e. vice - was in a similar way treated as a personal shortcoming, and a departure from the norms defining a good man and citizen. ${ }^{56}$

Virtues and vices were also the central motif in the most important texts of the classical canon of the eighteenth-century school. Works as Cicero's treatise on friendship or Cornelius Nepos' biographies acted in rhetoric instruction not only as stylistic models but also as bearers of a moral educational content. ${ }^{57}$ Here too the image evoked was that of the good man and citizen. According to Cicero he was wise, faithful, generous, just, steadfast, and so on - to compare with his wicked opposite: the greedy, jealous, lecherous and cruel man. ${ }^{8}$ Cornelius Nepos further embellished this picture, both regarding virtues (as wisdom, justice, altruism, generosity, and moderation) and vices (as greed for power and money, envy, wastefulness, debauchery, and cruelty). ${ }^{59}$ As was the case with the ideals stressed by the moral educational content in Elementa rhetorica, here could be found ancient notions of the right and wrong ways to be a man, citizen and human being. Needless to say, in some cases these Antique, pagan masculine ideals could differ quite a bit from the Christian pious virtue that was the overall aim of the moral education in schools and gymnasiums.

The exercises of the rhetorical educational programme also had moral aspects, clearly observable in for example the frequent mentions of virtue and vice in preserved translation and imitation exercises. This is striking when you examine the exercises written by the nine-year-old Johan Peter Carlmark as a schoolboy in Skara in the late 178os. Carlmark's exercise books are still kept in Skara, and constitute a rare but typical example. ${ }^{60}$ In the (sometimes badly spelled) Swedish and Latin parallel texts, the twofold educational objective is evident. ${ }^{61}$ Virtue is the most important motif, presented as one of the main goals in human existence, and ultimately what defines a human being. ${ }^{62}$ Among the virtues that distinguish

54 Cf. Rimm, Vältalighet och mannafostran, 204-211; also Rimm, Rhetoric, Texts and Tradition in Swedish 18th Century Schools, 16if.

55 Cf. Rimm, Vältalighet och mannafostran, 204-211.

${ }^{6}$ Cf. Rimm, Vältalighet och mannafostran, 211.

57 Cf. Rimm, Vältalighet och mannafostran, 211-222.

$5^{8}$ Cf. Rimm, Vältalighet och mannafostran, 212-215.

59 Cf. Rimm, Vältalighet och mannafostran, 213-222.

${ }^{60}$ Cf. Johan Peter Carlmark, Thema-bok [1], 1788, Carlmarks samling 63:1, Skara Stifts- och landsbibliotek, Skara. Johan Peter Carlmark, Thema-bok [2], 1788, Carlmarks samling 63:1, Skara Stifts- och landsbibliotek, Skara.

${ }^{61}$ Cf. Rimm, Vältalighet och mannafostran, 223-231.

${ }^{62}$ Cf. Rimm, Vältalighet och mannafostran, 229-231. 
a good person are piety, diligence, good character, wisdom and rationality. ${ }^{63}$ In contrast to this ideal appears the idle, the lazy, the hypocritical, and the ungrateful. ${ }^{64}$ This spectrum of virtue and vice is a standard by which both the school boys and their fellow human beings can be measured. Even though the virtues in these writing exercises seem more Christian and Protestant than the virtues in the mainly pagan texts of the classical authors, they still contain traces of antique civic ideals. As the foremost of exempla, however, Christ stands out: the role model for every pious boy and young man.

\section{Erudite eloquence and the spaces for socialisation}

The central scene for the education in rhetoric, and the erudite eloquence to which the education was aiming, was the school room. ${ }^{65}$ Here the classical authors were read - aloud -, and here the texts that pupils themselves wrote were scrutinized publicly. Here, both the theoretical study of rhetoric and the imitation of the classical authors were put into practice: here the pupils gave practice speeches and here they met in debate exercises. Here the clergy came for pastoral disputations, and here local elites were invited in order to attend teachers' appointments or celebrations and festivities. The very school building was a temple to eloquence - a clear contrast from the surrounding community. The pupils entered this building as boys, spent their time there as youth, and finally left to continue along the learned path as young men.

This way, the learned world in and around schools and gymnasiums can be considered a pre-modern or early modern public sphere. ${ }^{66}$ This public sphere was filled with rhetorical ceremonials as a display of erudition and scholarly status. At the school level rhetoric was a representative resource that could justify the position of the scholarly community and the clergy, demonstrate the standing of the school and the church site in the city, and distinguish the learned men from other social groups. ${ }^{67}$ The representative erudite eloquence of the eighteenth-century schools and gymnasiums was something that the pupils too could benefit from: as speakers at ceremonies, as audience, or simply as up-and-coming members of the clergy. During his time at school and gymnasium, a pupil could thus develop as a speaker from a school boy in a crowd of peers to a scholar in the making. The school houses and their extrovert displays of eloquence should therefore be regarded as crucial spaces for the socialisation of learned men-to-be.

The rhetoric education in schools and gymnasiums appears as one of the most distinct illustrations of the early modern Swedish school's twofold objective to transmit knowledge and instill virtue. The rhetorical pedagogical programme was not just about the arts and crafts of linguistic ornaments. One reason for this was the proximity to history and the

\footnotetext{
${ }^{6}$ Cf. Rimm, Vältalighet och mannafostran, 232.

${ }^{64}$ Cf. Rimm, Vältalighet och mannafostran, 232.

65 Cf. Rimm, Vältalighet och mannafostran, 251-265. Normally there were no class rooms as we know them today; all the classes were simultaniously taught in the same room, cf. Rimm, Vältalighet och mannafostran, $252 \mathrm{f}$.

66 Cf. Rimm, Vältalighet och mannafostran, 264. 268f. 272-274.

67 Cf. Rimm, Vältalighet och mannafostran, 274 .
} 
exempla that populated it: a treasure trove of historical and moral content and a common set of references transgressing generation and (vernacular) language barriers. Here too the traditions from Antiquity were evident. Apart from the all-important Latin, the historical, literary, rhetorical and mythological legacy of Roman and Greek culture were used in creating an erudite image. ${ }^{68}$ Even the smallest school or gymnasium could employ the imagery. The school house was Helicon; here the muses sang. ${ }^{69}$

The intellectual and rhetorical aspirations sometimes stand out in stark relief to the material conditions facing pupils and teachers. Beneath the Latin maxims adorning the walls, the school room was a crowded and noisy, and often cold and gloomy, space..$^{70}$ The everyday life of a schoolboy indeed lacked the grandeur and drama of the Greek, Roman and biblical exempla. The elaborate orations and formal disputations inside the schools and gymnasiums can be contrasted with life in the towns outside the walls of the school houses, where the pupils engaged in conflicts and confrontations with soldiers, apprentices and other groups of young men. ${ }^{71}$ The formation of virtuous character and learned identity thus took place in a world of contrasts and contradictions: between the ancient and the early modern world, between different perceptions of virtue and manliness. ${ }^{72}$

Through the reading of the exemplary texts and the moral lessons taught by them, and through pupils' own co-creation and rhetorical (re)production a classical, medieval, Renaissance and Reformation legacy was passed on. To this legacy belonged combining knowledge and virtue in the upbringing of an orator. He, the orator, was the vir bonus of the erudite early modern Sweden, a classical scholar and a pious Protestant, a good citizen and a virtuous and eloquent man, emulating originally antique ideals in an increasingly modern world.

\footnotetext{
${ }^{68}$ Cf. Rimm, Vältalighet och mannafostran, $284 \mathrm{f}$.

69 Cf. Rimm, Vältalighet och mannafostran, 263.

70 Cf. Rimm, Vältalighet och mannafostran, 252-256.

$7^{1}$ Cf. Rimm, Vältalighet och mannafostran, 276-284.

$7^{2}$ Cf. Rimm, Vältalighet och mannafostran, 292.
} 